УAK 005.521:32

ББК 66.06

DOI 10.22394/1682-2358-2021-6-21-29

V.A. Kolesnikov, Doctor of Science (Politics), Honored Worker of Higher Education of the Russian Federation, Professor of the Public Administration and Management Department, Volgograd Institute of Management, Branch of the Russian Presidential Academy of National Economy and Public Administration

V.Yu. Podurueva-Miloevich, post-graduate student of the Public Administration and Management Department, Volgograd Institute of Manasement, Branch of the Russian Presidential Academy of National Economy and Public Administration

\section{ROLE OF POLITICAL MEDIATION WITHIN THE SYSTEM OF POLITICAL POWER RELATIONSHIPS IN MODERN RUSSIA}

The authors study the phenomenon of "political mediation" and determine the mediation role of the subjects in the Russian Federation within the system "strong center - strong regions - effective local self-government". The problems of changing the current model of the federal structure are identified.

Key words and word-combinations: political and managerial mediation, system of government, political system modernization.
В.А. Колесников, доктор политических наук, заслуженньй работник вигсией иколь РФ, профессор кафедрь государственного упраљления и менеджмента Волгоградского института управления - филиала Российской академии народного хозяйства и государственной службь при Президенте РФ (email: kolesnikov-vags@mail.ru)

В.Ю. Подуруева-Милоевич, аспирант кафедрь государственного управления и менеджмента Волгоградского института управления - филиала Российской академии народного хозяйства и государственной службы при Президенmе РФ (email: viktorija-milojevic@yandex.ru)

\section{РОАЬ ПОАИТИЧЕСКОЙ МЕАИАЦИИ \\ В ОПОСРЕАОВАНИИ СИСТЕМЫ В $А$ АТНЫХ ОТНОШЕНИЙ СОВРЕМЕННОЙ РОССИИ}

\footnotetext{
Аннотация. Исследуется феномен «политическая медиация» и определяется посредническая роль субъектов РФ в системе «сильный центр - сильные регионы - эффективное местное самоуправление». Выявлены проблемы изменения в действующей модели федерального устройства.

Ключевые слова и словосочетания: политикоуправленческая медиация, система государственного устройства, модернизация политической системы.

\section{Востребованность}

политической медиации и исследования роли в управленческом проџессе на федеральном, региональном и местном уровнях власти неотделимы от перспективы модернизации политической системы России.
} 
В научных исследованиях политическая медиация интерпретируется неоднозначно, со смысловыми отличиями. Акцентируя политико-управленческий аспект политической медиации, остановимся на посреАнической функции региональной власти в трехуровневой системе власти Российской Федерации. Роль политической избыточности регионов в этой системе недооценена и мало исследована.

Рассмотрим научные представления о политической медиации и роли государства при ее осуществлении. Попытаемся определить роль политической медиации в системе властеотношений Российской ФеАераџии, выявить и охарактеризовать значение политико-управленческой медиации в опосредствовании системы властных отношений современной России.

Государственное управление на уровне субъектов РФ «коррелятивно “срединной” составмяющей общегосударственной системы управмения» [1, с. 181]. Срединный государственно-управменческий уровень на правовой основе "опосредует единение верхнего и низового уровней» [1, с. 181] федеральной модели государственного устройства России. В «трехуровневой системе публичной власти (федеральный, региональный, муниципальный) властные управленческие структуры реализуют предметы собственного ведения, а с этим в силу принципа "субсидиарности" - наделенную и делегированную компетенцию. Например, органы исполнительной власти в муниципальных образованиях со статусом городских округов, муниџипальных районов наделяются отдельными государственными полномочиями» [1, с. 181] .

В.Е. Чиркин считает, что «субъекты РФ имеют свои основные законы (в том числе конституции), вправе законодательствовать по определенному кругу вопросов, имеют собственные органы исполнительной власти, частичную судебную власть и некоторые Аругие признаки государственности. <..> Управление субъектов РФ осуществляется в пределах полномочий, установленных федеральной Конституцией и федеральными законами» [2, с. 31]. На органы государственной вмасти субъектов Федерации (шести конституционных типов) возмагаются задачи проведения государственной политики; управмение соџиальноэкономическим развитием и обеспечение политической стабильности на территории региона; опосреАствование отношений федерального и регионального, регионального и муниципального уровней общегосударственной системы управления власти; гарантии и государственная поддержка местному самоуправлению. Существенна региональная ответственность за реализацию принципа народовластия: многонациональный народ - субъект принятия Конституции, носитель суверенитета и единственный источник власти в Российской Федерации. В 
соответствии с ч. 2 ст. 3 Конститущии РФ «народ осуществляет свою власть непосредственно, а также через органы государственной власти и органы местного самоуправления» [3, с. 4].

Осмысление политико-медиативной роли субъектов РФ требует пояснения инструментальных понятий: «медиация», «политическая меАиация». Термин «медиация» в управленческой системе характеризует опосредствование отношений ветвей и уровней власти, институтов управления. Наиболее известен институт медиации посредством деятельности омбудсмена (уполномоченного по правам человека). Явцяясь производным от представительного органа народовластия, «омбудсмен реализует функщию защиты конститущионных прав граждан от проявмений некачественного государственного управления (термин «плохое управление» - «Maladministration» - введен мейбористами Англии и закреплен в «перечне Кроссмана», по имени министра, ответственного за подготовку Закона о парламентском уполномоченном по правам чемовека в 1965 г.) [4]. Парламентский уполномоченный, «омбудсмен» Великобритании, представмяет ежегодный докмад о типичных нарушениях прав граждан, неэффективности деятельности органов государственного управления.

В отечественной научной митературе приоритетны исследования медиативного фактора в аспекте построения правового государства в Российской Федерации, при этом востребовано осмысление медиации как социокультурной категории [5, с. 27], технологии преодоления корпоративных конфциктов в сфере предпринимательства [6, с. 13], опосредствования в механизмах взаимодействия и разрешения противоречий посреАством компромиссов [7, с. 46], выявмения устойчивости функционирования мунищипальных институтов и снижения конфииктности в местных сообществах [8, с. 204]. Принцип управменческой медиации (через призму обеспечения прав граждан) востребован дмя достижения эффективности управления на всех уровнях институциональной управленческо-административной деятельности. В США, например, в вузовской системе наряду со студенческим самоуправлением действуют и студенческие омбудсмены [4] .

В управленческой практике демократических стран медиация рас-

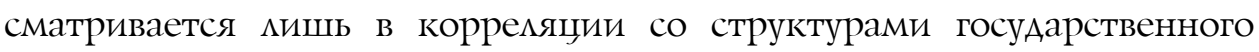
надзора и законности: атторнеи - прокуроры, аудиторы и асессоры, судебные и полицейские органы и прочие. ОАнако политическая медиащия крайне важна при исследовании отношений государства и природы, влияния на экологию, в мировой экономике [4; 6; 9, с. 24; 10; 11], в сфере изменения отношений государства и материальной культуры $[5 ; 12 ; 13]$. 
В механизме государственного устройства Российской Федерации важна определенность политической медиации в варианте «политико-управленческой» медиации. В.В. Гайдук и А.С. Аукьянов сущность политической медиаџии сводят к технологии «ацьтернативного экспертно-политологического разрешения споров и урегулирования споров... исходя из солидарного стремления к Аостижению соглашения и политической объективности и целесообразности» [11, с. 83-84]. Выдающийся русский философ И.А. Ильин политическую медиаџию рассматривал как примирительно ориентированное разбирательство на почве политически значимых споров сторон с участием примирительных институтов. Осмелимся утверждать, что нормативистский подхоА ориентирован на понимание политической медиации мишь как разрешительно-процедурного инструментария компромиссов субъектов помитического конфликта с подключением медиатора-посредника.

Политическая медиация, однако, не может быть сведена к техномогии разрешения политических разногласий, а при нормативистском подходе медиатор-посредник востребован исключительно в такой ситуации. Это и институщионально-управленческий феномен опосредствования властных отношений и уровней власти в системе государственного устройства, обеспечения эффективности взаимосвязи государственных институтов. Политическая медиация выявцяет политико-управленческую предикативность в механизме функщионирования властеотношений. Институционально-управленческий аспект политической меАиации существен для анализа системы государственного управления по ряду причин: а) он конкретизирует особенности взаимодействия субъектов политического и управленческого процессов; б) способствует выявлению опосредствующего фактора регионального государственного управления и преодолению устаревших компонентов проведения государственной политики в субъектах РФ; в) ориентирует на поиск новых форм в государственном строительстве в целях успешности Российского государства [13, с. 25-29].

Требует, на наш взгляА, уточнения и содержание понятия «государство». Государство исследуется, как правицо, в двух аспектах. Широкий смысловой аспект характеризует государство как социетальное образование, что важно дия понимания исторического развития типов госуАарств. Второй аспект - это понимание государства как политического субъекта управления страной и обществом. При этом Аоминирует классовое понимание характера государства, так как при отсутствии массива среднего кмасса (социальной базы укоренения демократии и преодоления жестких авторитарных режимов) общественные интересы развития могут не совпадать с интересами правящего класса и

24 Bulletin of the Volga Region Institute of Administration 2021. Vol. 21. № 6 
господствующей элиты. Ресурсы страны и общества в ресурсозависимом государстве используются по преимуществу в интересах правящего класса.

Второй аспект понимания государства (его субъектность и ответственность, формы достижения политико-управленческих и экономикохозяйственных результатов) часто камуфлируется первым, но конкретен Аля выявления особенностей политической медиации, противоречий в политических системах. Государство выявляет ориентиры на проведение государственной политики как институциональная структура, не совпадающая с целостностью конкретного соџиума. В отношениях с государством могут функционировать формы негосударственной хозяйственной собственности, негосударственные институты, самоорганизованные структуры гражданского общества, церковь, отделенная от государства, и прочее. Государство можкет конкретизироваться в определении его сушности как политико-управленческий субъект и аппарат управления обществом, при этом в управленческом механизме аккумулируется триединство ветвей и уровней государственной власти. Важны способы и формы государственного управления в рамках конкретных типов политического и государственного режкимов (предикаты коррелятивные, но не тождественные). Подобно этому понятия «реа$\Lambda$ истичное государство» и «реальное государство» могут не совпадать в этом аспекте, как не совпадают по цемям «соџиальное государство» и «социалистическое государство».

В управленческом аспекте существенно понимание политико-медиативной функщии государства в отношении общества и конкретных соџиальных слоев, использования общественных ресурсов, отношения к многонациональному народу суверену, признаваемому единственным источником власти в Российской Федераџии (ст. 3 Конституџии РФ). Неверно, однако, считать, что авторитарное государство несовместимо с экономическим развитием. Это возможно, но при условии, что в экономической сфере правительство сообразуется с принципами правового государства: допускает диверсификацию и защиту собственности. На практике государства с авторитарными режимами тяготеют к автократии в той мере, какими обладают ресурсами, какие используют технологические передовые знания, часто производимые странами с демократическими и миберальными режимами. Только демократический тип государства в состоянии поощрять весь творческий потенциал общества, гарантировать развитие свободной индивидуальности, эффективно соотносить экономическую и политическую формы конкуренции.

Все это целесообразно учитывать при исследовании медиативной роли государственных органов, особенно на уровне субъектов РФ, когда 
акцентируется необходимость устойчивости политико-управленческого потенциала в «триединстве уровней власти», в функционирующей моАели российского федерализма. Аействующую российскую феАеральную модель «... можно охарактеризовать как унитарный федерализм» с повышенной центрахизацией власти [12, с. 13] и как пирамидальную систему, в которой государственное управление усилено многообразием конституџионных полномочий по предметам ведения Российской Федераџии и совместного ведения с субъектами РФ (в этих полномочиях доминирует интерес центральной власти, закрепленный своеобразием бюджетного федерализма).

Сфера совместного ведения - противоречивая область внутригосуАарственных отношений. Отметим сохраняющую значимость проблему разграничения полномочий межАу уровнями власти, необходимость минимизации предметов совместного ведения Российской Федерации и субъектов РФ. ЗАесь фокус перехода от доминанты договорного права в Российской Федерации (особенно с республиканскими субъектами) к законности на основе Конституции РФ и федеральных законов к полноте равноправия во взаимоотношениях субъектов РФ с федеральным центром и равноправия субъектов РФ во всех видах взаимодействия.

К середине 2000-х годов федеральный центр усилен системой оперативных мер по восстановлению вертикали исполнительной власти с целью «прекрашения» центробежной тенденции на уровне субъектов РФ. Критика модели федерализма и поиск перспектив, ориентированных на укрупнение российских регионов, как и востребованность новой реформы местного самоуправления, были актуализированы в начале 2000-х годов. Говорилось о необходимости поставить «пирамидальную» модель федерализма с острия на основание («с головы на ноги») [14] с четким закреплением полномочий по уровням системы общегосударственного управления [10, с. 73]. В цемях этой стратегии осуществлена новая реформа муниципальной системы на основе Федерацьного закона от 6 октября 2003 г. № 131-Ф3 «Об общих принџипах организаџии местного самоуправления в Российской Федерации», пришедшим на смену Федеральному закону от 25 августа 1995 г. № 154 [15] .

Региональный уровень государственного управления в Российской Федераџии сегодня в самостоятельности ограничен, в связи с этим проявцяются значительные отличия и неравномерность в экономическом развитии субъектов Федерации. Это коррелирует и с неразвитостью межрегиональной системы рыночных отношений (выделяется небольшая группа регионов-доноров). Муниџипальная подсистема (третий уровень системы публичной власти в Российской Федерации) остается зависимой от уровня развития и самостоятельности регионов со слабой

26 Bulletin of the Volga Region Institute of Administration • 2021. Vol. 21. № 6 
налогооблагаемой базой и значительной дотационной государственной поддержккой (особенно сельских населений). В хозяйственной жкизнедеятельности муниципальных образований выявцяются устойчивость государственного Аирижизма к органам местной вмасти и тенденџия к минимизации поселений (городских и сельских в составе муниципальных районов), укрупнению посреАством городских округов.

Повышение медиативно-управленческой роли российских регионов возможно в перспективной модели «сильный центр - сильные регионы - эффективное местное самоуправление». Констатируется необходимость перехода к модели «субъект-субъектного» взаимодействия местной власти и насемения муниципальных образований - важнейшего условия разрешения противоречий на новом этапе государственного строительства России [16, с. 35]. 3Аесь и ориентир на новые формы ответственности губернаторского корпуса Российской Федерации, и новое качество систем исполнительной власти (региональное государственное управление) субъектов РФ в трехуровневой властной системе. Сегодня в механизме укрупнения и унификации региональной субъектности наблюдается заметное торможение. Однако в стране функционирует девять субъектов краевого типа: укрупнение 2003 г. на основе объединения Пермской области с Коми-Пермятским АО в Пермский край (модель «Ава в одном»); преодоление статуса субъектов Федерации у Эвенкийского и Таймырского АО, интеграция Красноярского края закреплены в модели «три в одном» и т.п.

Процесс образования новых укрупненных регионов (края, губернии или все - с унифиџированным статусом республики подобно федеральным землям в ФРГ, штатам в США как субъекты федераџии с республиканской формой правления и запретом на «сецессию») не обрел полноты динамики. Этот процесс приостановлен в сику приоритета стабицьных межнационацьных отношений, сложности механизма финансового и организационного объединения республик в составе Российской Федерации. К проектному моделированию нового типа укрупнения российских регионов целесообразно, на наш взглял, преАложить вариант использования территории одного из федеральных округов как территориальный «полигон» и модельную форму объединения субъектов, хозяйственной интеграции в рамках нового укрупненного субъекта РФ.

Переход к перспективной модели федерального обустройства Российской Федерации - необходимость, и он потребует, возможно, конституџионной реформы, не менее значимой, чем иниџиированная в 2020 г. На ближайший период реальной представмяется, однако, не интенсифицированная унификация правового статуса субъектов РФ, а 
сохранность асимметрии правового статуса иных субъектов РФ с республиканскими субъектами (конституционная норма ст. 5 «республики-государства» в составе Российской Федерации). При этом остается востребованным ориентир к повышению политико-медиативной роли действующих сильных субъъектов РФ в общегосударственной системе, а также повышение их влияния на центральную власть в общегосударственной системе устройства вцасти и управления.

Таким образом, политическая медиация, исследованная с выходом за рамки нормативистского подхода, приводит к пониманию ее как институционально-управленческого феномена опосреАствования в системе взаимодействия уровней государственного устройства.

В рамках осмысления феномена «политическая медиаџия» определена медиативно-управленческая (опосредническая) роль субъектов РФ в системе «сильный центр - сильные регионы - эффективное местное самоуправление» в современной России. Уровень функционирования региональных органов власти и государственных институтов получает особую политико-управленческую предикативность в российской трехуровневой системе властеотношений.

Выявленные проблемы системного характера в действующей моде$\Lambda и$ федерального устройства Российской ФеАерации (количественное многообразие субъектов РФ, асимметрия правого статуса субъектов РФ, неравномерность экономического развития субъектов РФ) требуют комплексного исследования медиативной роли субъектов РФ как политико-управленческого основания и потенџиала в новой перспективной модели российского федерализма и государственного устройства.

\section{Библиографический список}

1. Колесников В.А., Романенко Д.Д. Политическая медиация: идентификация содержания // Теории и проблемы политических исследований. 2020. Т. 9, № 1А. С. 180-188.

2. Чиркин B.E. Российская Конституция и публичная власть народа // Государство и право 2008. № 12. С. 24-34.

3. Конституция Российской Федерации (принята всенародным голосованием 12 дек. 1993 г. с изм., одобренными в ходе общероссийского голосования 1 июля 2020 г.) [Электронный ресурс]. Доступ из СПС «КонсультаетПлюс».

4. Бойцова В.В., Бойцова Л.В. Правовой институт омбудсмена // Полис. 1993. № 1. C. $183-190$.

5. Давыдов А.П., Розин В.М. Спор о медиации: Раскол в России и медиация как стратегия его преодоления. М., 2017.

6. Бегаева А.А. Институт медиации - альтернативный способ разрешения корпоративных конфликтов // Предпринимательское право. 2008. № 3.

7. Рюмшин С.А., Юдин В.И. Медиация - социальное взаимодействие в преодолении противоречий и конфликтов через компромисс // Этносоциум. 2015. № 10. 
8. Козюк М.Н. «Миру мир»: медиативная технология снижения социальной конфликтности в местных сообществах. Волгоград, 2017.

9. Хиль-Роблес А. Институт омбудсмена // Городское самоуправление. 1998. № 8.

10. Выдрин И.В., Эмих В.В. Принцип субсидиарности в организации местного самоуправления в России и Польше // Научный ежегодник Ин-та философии и права Урал. отд-ния РАН. 2017. Т. 17, вып. 2. С. 71-99.

11. Гайдук В.В., Лукьянов А.С. Политическая медиация как новая политическая технология // Вопросы политологии. 2014. Вып. 4(16).

12. Казаков А.А. Какой федерализм нужен? // Российская Федерация сегодня. 2005. № 5 .

13. Качество и успешность государственных политик и управления. Сер.: Политическая аксиология. М., 2012.

14. Медведев В. Опрокинутая пирамида, или Особенности российского федерализма // Сайт фонда Единство Нации. URL: http:// nacidea. ru/text/ 19908n 15. Shtml.

15. Об общих принципах организации местного самоуправления в Российской Федерации: Федер. закон от 6 окт. 2003 г. № 131-Ф3 // С3 РФ. 2003. № 40. Ст. 9502.

16. Колесников В.А., Пахомов Д.В., Подуруева-Милоевич В.Ю. Государство и местное самоуправление: ориентиры развития и политический выбор России // Теории и проблемы политических исследований. 2020. Т. 9, № 1А. С. 34-43.

17. Афанасьев М.А. Российская элита развития: запрос на новый курс. М., 2009. C. 83-86. 